\title{
The Production of Bioethanol from Rimau Gerga Lebong (Rgl) Orange Waste as an Alternative Energy
}

\author{
Vike Darliyasi ${ }^{1}$, Kurnia Herlina Dewi ${ }^{2 *}$, Budiyanto ${ }^{2}$ \\ 1) Student of Agricultural Technology, Faculty of Agriculture, University of Bengkulu \\ ${ }^{2)}$ Department of Agricultural Technology, Faculty of Agriculture, University of Bengkulu, Indonesia
}

\begin{abstract}
Bioethanol from Rimau Gerga Lebong (RGL) orange waste is one of the solution to overcome fuel oil problem. The aim of this research is to get the type of microorganisms and fermentation time that produce the highest ethanol from RGL orange waste. The research method used was Randomized Block Design (RBD) of two factors, namely type of microorganisms (Trichoderma viride, Saccharomyces cerevisiae, and Trichoderma viride + Saccharomyces cerevisiae) and fermentation time (3 days, 5 days, and 7 days. Within the three type of microorganisms with variations of fermentation time showed that the $\mathrm{pH}$ was able to carry out the fermentation process smoothly. The highest total dissolved solids were in the type of Trichoderma viride 3 days and 5 days, and the type of mix of microorganisms on the $3^{\text {rd }}$ day. The highest ethanol content is in the type of Sachharomyces cerevisiae for 7 days. ANOVA result showed that the interaction between two treatments on the total dissolved solids experienced significant differences, so it continue with the DMRT test at a significant level of $0.5 \%$. However, it is different from the results of ANOVA on ethanol content which showed that there were significant differences between ethanol content and types of microorganisms, but there was no significant difference on fermentation time
\end{abstract}

\section{Introduction}

Orange is one of the fruits which containing cellulose. Orange juice contains cellulose around 0,52 gram per $50 \mathrm{ml}$ and cell wall of orange fruit contain cellulose of $25-35 \%$ [1], orange peel contains cellulose of 5.36\% [2]. [3] Reported that orange fruit yield ethanol levels of $9.75 \%$ on acid hydrolysis. Whilst, [4] utilizing orange peel with enzymatic hydrolysis resulted in the highest ethanol content of $40.298 \%$.

According to the Central Bureau of Statistics, the production of orange fruit in the province of Bengkulu reached 10,132 tons. Rimau Gerga Lebong (RGL) orange is originally orange species, which developed in Bengkulu Province. This orange becomes the preeminent commodity of Lebong Regency [5]. RGL orange have competitive advantages, namely the colour of yellow-orange fruit, fruitful throughout the year, large fruit size, high

\footnotetext{
*Corresponding author: nia_unib@yahoo.com
} 
fruit juice and also has a good market potential as the demand for orange RGL reached 100 tons/month, and contains 11.4 grams of carbohydrates [6].

About $30 \%$ of fruit fall due to various factors is one of shortcoming of RGL orange, and it makes farmers often suffer considerable losses [7]. The fallen fruit directly throw away as a waste, even though the content of the cellulose can be processed into bioethanol, whether by means of (1) hydrolyzing cellulose into glucose (reducing sugar) using acid or enzyme or (2) reshuffling glucose (reducing sugar) to ethanol. The enzymatic breakdown of cellulose using cellulose enzyme, while Saccharomyces cerevisiae is widely used for ethanol fermentation

This study aims to obtain the type of microorganisms and fermentation time that can produce the highest ethanol from bioethanol manufacture of Rimau Gerga Lebong (RGL) orange waste.

\section{Research Methods}

The materials used are whole fruit of RGL orange waste, aquades, Saccharomyces cerevisiae and Trichoderma viride.

Randomized Block Design (RBD) used with 2 factorial i.e. microorganism type and fermentation time. Microorganism type consists of Trichoderma viride, Saccharomyces cerevisiae and mixture of Trichoderma viride + Saccharomyces cerevisiae respectively. Meanwhile, the fermentation time selected 3,5 and 7 days respectively. Each treatment repeated three times ( 27 experimental units).

\subsection{Preparation of Raw Material}

RGL orange waste directly blended without sterilization process. The raw material is prepared by using $\mathrm{NaOH}$ until it reaches $\mathrm{pH} 5$ for the fermentation, which Trichoderma viride used as the microbial, and $\mathrm{pH} 3.92$ for Saccharomyces cereviseae. Then stirred for homogeneous and put it into container fermenters.

$500 \mathrm{ml}$ of RGL orange waste is then fermented. Fermentation carried out in three types, namely, using $10 \mathrm{ml}$ Trichoderma viride, 4 grams Saccharomyces cerevisiae and mixed of $10 \mathrm{ml}$ Trichoderma viride +4 grams Saccharomyces cerevisiae. Enzymatic hydrolysis carried out first for the mixed fermentation process, using Trichoderma viride for 3 days. Then incorporate 4 grams of Saccharomyces cerevisiae and conducted the fermentation process for 3,5 and 7 days. The next step was distillation, aims to separate ethanol from other products. The distillation would be conducted by simple distillation with $78^{\circ} \mathrm{C}-90^{\circ} \mathrm{C}$ for 5 hours

\subsection{Data analysis}

The data obtained plotted to found out the relationship of treatment observation parameters. Data analysis using ANOVA (Analysis of Variance) was used to determine the effects of treatment on observation result, if the ANOVA result was significantly different, and then continued with DMRT (Duncan Multiple Range Test) test at $0.5 \%$ significant level.

\section{Results And Discussion}

\subsection{Changing $\mathrm{pH}$ on the Fermentation Process}

$\mathrm{pH}$ is one of the important factor that can affect in the growth of microorganisms and final product on the fermentation process. All the types of microorganisms which used in the 
fermentation process shows that the longer the fermentation the more the $\mathrm{pH}$ decreased, as shown in figure 1 . The occurrence of $\mathrm{pH}$ decline is caused by many factors, such as the presence of byproducts produced resulting in a decrease $\mathrm{pH}$. Each microbes can work to produce something that suits their respective roles, so it needs the optimal $\mathrm{pH}$, as in the fermentation with Trichoderma viride that can produce rough cellulose enzymes

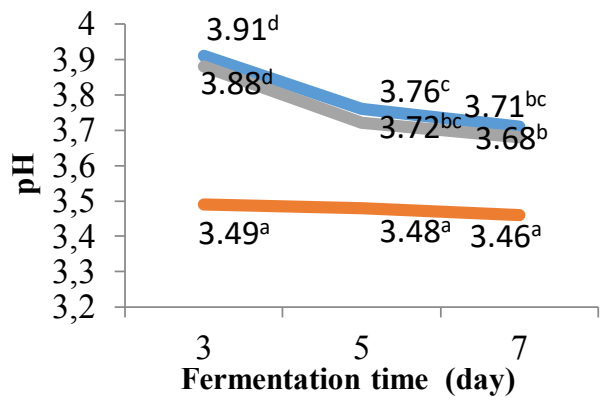

Trichoderma viride

Saccharomyces cerevisiae

Trichoderma viride + Saccharomyces cerevisiae

Fig. 1. Graph of $\mathrm{pH}$ on the Fermentation of Bioethanol RGL Orange Waste

\subsection{The Changing of Glucose Levels}

Bioethanol is ethanol derived from ingredients that contain carbohydrates or glucose, so the role of glucose itself is essential to produce high levels of ethanol. Figure 2 showed that the highest glucose levels are in the type of Trichoderma viride microorganisms in which this type of microbe can produce cellulose enzymes that function to convert cellulose to glucose. The process of changing cellulose to glucose using this cellulose enzyme namely enzymatic hydrolysis. On the 3rd and 5th days the highest glucose level, which was 7.05 brix, decreased on the 7th day by 6.03 brix. The tendency to increase glucose levels during enzymatic hydrolysis is suspected, because at the beginning of enzymatic hydrolysis the synergistic cellulose activity between endoglucanase, cellobiohydrolase, and beta-glucosidase. Endoglucanase hydrolyzes the 1,4 binding randomly and acts on the amorphous portion of cellulose fibers. Furthermore, cellobiohydrolase hydrolyzes the ends of cellulose chains to produce cellobiose, where they are hydrolyzed by $\beta$-glucosidase to glucose.

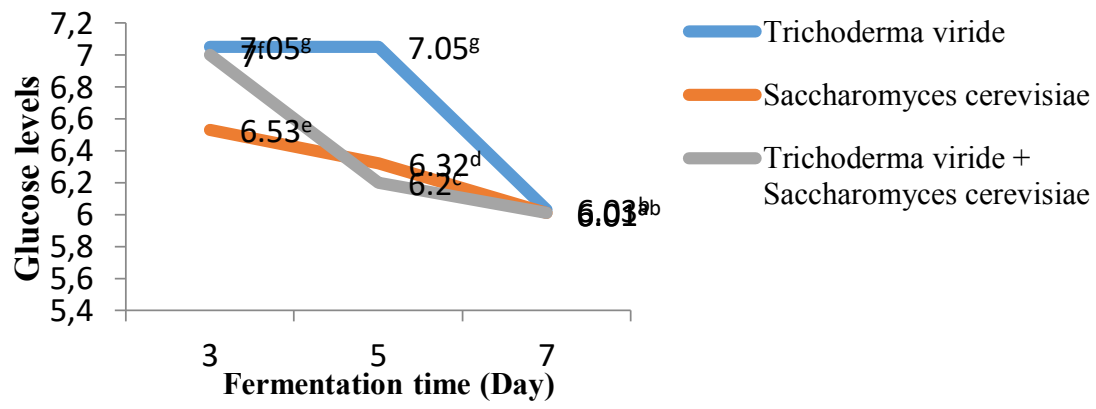

Fig. 2. Graph of Glucose levels of Bioethanol RGL Orange Waste

Fermentation using Saccharomyces cerevisiae microbes produce the lowest glucose levels than others. This is because Saccharomyces cerevisiae can convert glucose into ethanol, so that the glucose content contained in the raw material is directly converted to ethanol, which will cause the glucose level to decrease as it has been converted to ethanol. 
Similarly, mixed fermentation using a mixture of enzymatic hydrolysis results for 3 days followed by the addition of Saccharomyces cerevisiae.

ANOVA analysis proof that type and length of fermentation were significance to glucose level so that tested continued to DMRT (Duncan's multiple range test) at level 5\%

\subsection{The Changing of Ethanol Levels}

Ethanol content obtained from the distillation by using a simple distillation tool and measured using a $25 \mathrm{ml}$ pycnometer. The result then converted by using alcohol metric table. Result of analysis of average ethanol level to treatment factor shown in figure 3.

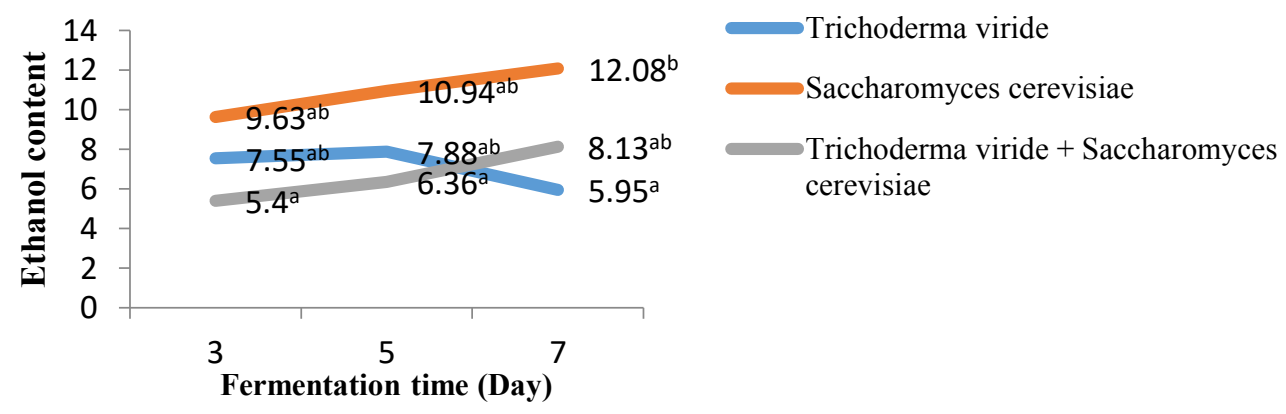

Fig. 4. Graph of Ethanol content of Bioethanol RGL Orange Waste

Based on the figure 4, the type of microorganisms that produce the highest ethanol is the Saccharomyces cerevisiae microorganism, which increases day by day. This is because yeast works well in converting glucose to ethanol. In this process, glucose is not directly converted to ethanol. The yeast will convert glucose and fructose into pyruvic acid through the reaction stage of the Embden-Meyerhof-Parnas pathway, which will then proceed, with the process of decarboxylation of pyruvic acid into acetaldehyde. Acetaldehyde then undergoes dehydrogenation process into ethanol compounds.

However, this result inversely proportional to the fermentation using Trichoderma viride, which is up and down. The occurrence of a decrease on the 7th day is due to the resulting glucose levels is also small which will lead to low levels of ethanol. So, the role of Trichoderma viride microbe is not to produce ethanol, but convert cellulose into glucose, but when distilled and measured ethanol content, this type of microbe can produce ethanol as well. This is allegedly due to the presence of natural microbes that can directly convert raw materials into ethanol. This also proven by spontaneous fermentation experiments on RGL orange garden waste, i.e. without any microbial mixture, the results obtained in the form of spontaneous fermentation can produce ethanol, even the ethanol content is small.

In contrast to the fermentation type of mixtures, in which can produce the highest levels of ethanol compared to others, because the working microbes have also been maximized, such as Trichoderma viride, which can convert cellulose into glucose, and Saccharomyces cerevisiae, which can convert glucose into ethanol. Although the results are less than the type of fermentation using Saccharomyces cerevisiae alone, but this type of fermentation increases day by day.

ANOVA test showed that fermentation type significantly different to ethanol content, but there is no different with fermentation time.

\section{Conclusion}

The results concluded that: 
1. The microorganisms that produce the highest ethanol content was of microorganisms that use Saccharomyces cerevisiae

2. The fermentation time to produce the best ethanol content was 7 days, but there is no effect on the ANOVA.

\section{References}

1. Kadarisman, D., Sunarmani dan M. Arintawati.. Buletin Penelitian Ilmu dan Teknologi Pangan. Bogor. IV(1): 61-68. (2004)

2. Ichwani, R.. Pemanfaatan Limbah Kulit Jeruk Keprok (Reticulata Blanco syn) Sebagai Bahan Penguat Nanokertas Selulosa Bakteri dari Air Kelapa. Skripsi. Medan: Universitas Sumatera Utara. (2013)

3. Andini, C., E. Mahajoeno dan R. Setyaningsih. Production of Bioethanol From Citrus Fruit (Citrus Sp) Waste By Acid Hydrolysis and Fermentation Using Saccharomyces cerevisiae. Seminar Nasional X Pendidikan Biologi FKIP UNIS. Surakarta : Universitas Sebelas Maret. (2013).

4. Megawati dan R. Ciptasari.. Prosiding SNST ke-6. Semarang : Universitas Negeri Semarang. (2015)

5. Rambe, M dan S. Suryani. Menelisik Inovasi Gerga Bersama Bu Yeni. Badan Penelitian dan Pengembangan Pertanian Bengkulu. Majalah Sinar Tani Edisi 19 - 25 Agustus No.3619 Tahun XLV (2015)

6. Pancawarman, R. Permintaan Jeruk Gerga Lebih 100 Ton Perbulan. (http://www.antarabengkulu.com/berita/5129/lebong-kembangkan-jeruk-gerga . (2017).

7. Sugandi, D. Inovasi Teknologi Jeruk Gerga Harga Mati. Badan Penelitian dan Pengembangan Pertanian Bengkulu. Majalah Sinar Tani Edisi 19 - 25 Agustus 2015 No.3619 Tahun XLV. (2015). 